\title{
Significance of Transcription Factors in the Mechanisms of Great Artery Malformations
}

\author{
Yusuke Watanabe and Osamu Nakagawa
}

\author{
Keywords \\ Congenital cardiovascular disease $\cdot$ Great arteries $\cdot$ Notch signaling
}

Members of the Hey transcriptional factor family are Notch target genes [1], and they have unique and redundant functions in cardiovascular development. Among them, we recently reported that Hey 1 had an indispensable role for the great artery formation (Fig. 60.1) [2].

Dysfunction of several transcription factors is correlated with anomalies of the great arteries. Human $T B X 1$ is the gene responsible for $22 \mathrm{q} 11.2$ deletion syndrome, and mutant mice for $T b x 1$ recapitulate the phenotypes such as interruption of aortic arch type B and right-sided aortic arch. These defects are originated from the impaired development of the fourth pharyngeal arch arteries (PAAs) at early embryonic stages, and migration, proliferation and survival of the neural crest cells are affected in Tbxl mutant mice [3]. Similarly, the deficiency of upstream and downstream transcription factors of Tbx1, such as Foxc2, Gbx2 and Hes1, results in abnormal great arteries.

The malformation of great arteries in Heyl knockout mice is also associated with the fourth PAA defect although the expression of Tbx1 and target genes as well as the behavior of neural crest cells are normal [2]. Interestingly, the tubular endothelial structure is disturbed, and the expression of a Notch ligand, Jagged1, in endothelial cells is markedly reduced in the defective fourth PAAs of Heyl knockout embryos (Fig. 60.1) [2], suggesting that Hey1 is necessary for the endothelial organization of the fourth PAA. Elucidating the mechanism of Hey actions, especially

\footnotetext{
Y. Watanabe $(\triangle) \cdot$ O. Nakagawa

Department of Molecular Physiology, National Cerebral and Cardiovascular Center Research Institute, Suita, Osaka, Japan

e-mail: ywatanabe@ncvc.go.jp; osamu.nakagawa@ncvc.go.jp
} 
Fig. 60.1 Defects of great artery morphogenesis and pharyngeal arch artery development in Hey1 knockout mice

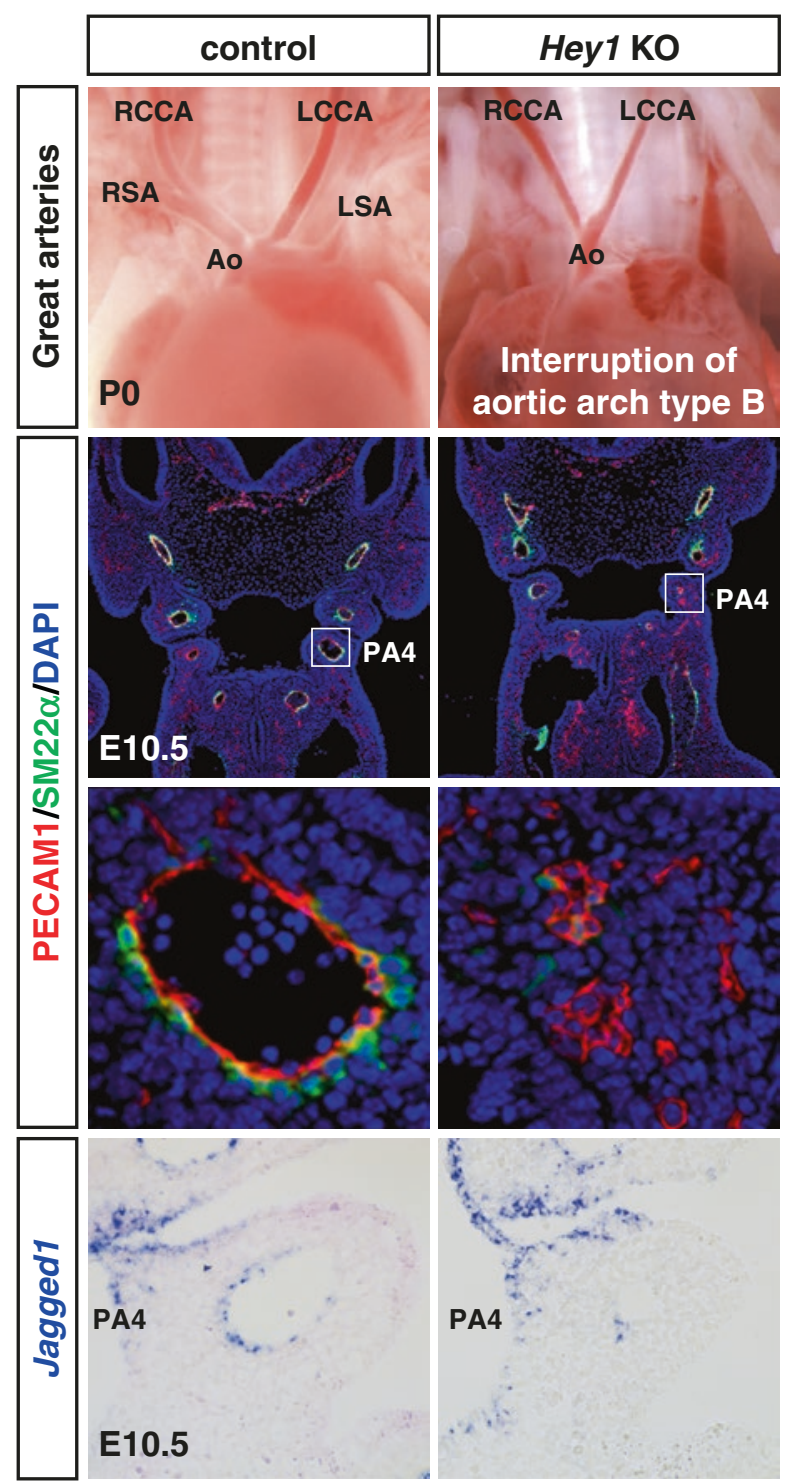


tissue specificity and direct target genes, and relationship with Tbx1 pathway will provide further understanding of the fourth PAA development and related human congenital cardiovascular diseases.

\section{References}

1. Nakagawa O, McFadden DG, Nakagawa M, Yanagisawa H, Hu T, Srivastava D, Olson EN. Members of the HRT family of basic helix-loop-helix proteins act as transcriptional repressors downstream of Notch signaling. Proc Natl Acad Sci U S A. 2000;97(25):13655-60.

2. Fujita M, Sakabe M, Ioka T, Watanabe Y, Kinugasa-Katayama Y, Tsuchihashi T, Utset MF, Yamagishi H, Nakagawa O. Pharyngeal arch artery defects and lethal malformations of the aortic arch and its branches in mice deficient for the Hrt1/Hey1 transcription factor. Mech Dev. 2016;139:65-73.

3. Lindsay EA, Vitelli F, Su H, Morishima M, Huynh T, Pramparo T, Jurecic V, Ogunrinu G, Sutherland HF, Scambler PJ, et al. Tbx1 haploinsufficiency in the DiGeorge syndrome region causes aortic arch defects in mice. Nature. 2001;410(6824):97-101.

Open Access This chapter is licensed under the terms of the Creative Commons Attribution 4.0 International License (http://creativecommons.org/licenses/by/4.0/), which permits use, sharing, adaptation, distribution and reproduction in any medium or format, as long as you give appropriate credit to the original author(s) and the source, provide a link to the Creative Commons license and indicate if changes were made.

The images or other third party material in this chapter are included in the chapter's Creative Commons license, unless indicated otherwise in a credit line to the material. If material is not included in the chapter's Creative Commons license and your intended use is not permitted by statutory regulation or exceeds the permitted use, you will need to obtain permission directly from the copyright holder.

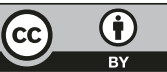

